\title{
Mice Deficient for Both Corticotropin-Releasing Factor Receptor 1 (CRFR1) and CRFR2 Have an Impaired Stress Response and Display Sexually Dichotomous Anxiety-Like Behavior
}

\author{
Tracy L. Bale, ${ }^{1}$ Roberto Picetti, ${ }^{2}$ Angelo Contarino,,2 George F. Koob, ${ }^{2}$ Wylie W. Vale, ${ }^{1}$ and Kuo-Fen Lee ${ }^{1}$ \\ ${ }^{1}$ Clayton Foundation Laboratories for Peptide Biology, The Salk Institute, La Jolla, California 92037, and ${ }^{2}$ Department of \\ Neuropharmacology, The Scripps Research Institute, La Jolla, California 92037
}

Corticotropin-releasing factor (CRF) and its family of peptides are critical coordinators of homeostasis whose actions are mediated through their receptors, CRF receptor 1 (CRFR1) and CRFR2, found throughout the CNS and periphery. The phenotypes of mice deficient in either CRFR1 or CRFR2 demonstrate the critical role these receptors play. CRFR1-mutant mice have an impaired stress response and display decreased anxiety-like behavior, whereas CRFR2-mutant mice are hypersensitive to stress and display increased anxiety-like behavior. To further elucidate the roles of both CRF receptors and determine their interaction in behaviors, we have generated mice deficient in both CRFR1 and CRFR2. The behavioral phenotype of these mice demonstrates a novel role of the mother's genotype on development of pup anxiety. We have found that although the female double-mutant mice display anxiolytic-like behavior, the male double-mutant mice show significantly more anxiety-like behavior compared with the females. We have also determined that the dam's CRFR2 genotype affects the anxiety-like behavior of the male mice, such that a pup born to a heterozygous or mutant dam displays significantly more anxiety-like behavior regardless of that pup's genotype. Double-mutant mice also display an even greater impairment of their hypothalamic-pituitary-adrenal axis response to stress than that of the CRFR1mutant mice. CRF mRNA levels are elevated in CRFR1- and double-mutant mice, and urocortin III and vasopressin mRNA levels are increased in CRFR2- and double-mutant mice. These results indicate that both $\mathrm{CRFR} 1$ and $\mathrm{CRFR} 2$ have critical roles in gene regulation and the maintenance of homeostasis in response to stress.

Key words: corticotropin-releasing factor; urocortin; urocortin III; maternal genotype; anxiety; stress
Corticotropin-releasing factor (CRF) is a critical coordinator of the hypothalamic-pituitary-adrenal (HPA) axis and is an essential component in mediation of behavioral responses to stress. The actions of CRF and urocortin (Ucn), a CRF-related peptide, in the regulation of homeostasis (Vale et al., 1981; Vaughan et al., 1995) are mediated via activation of their two known receptors, CRF receptor 1 (CRFR1) (Chen et al., 1993) or CRFR2 (Kishimoto et al., 1995; Lovenberg et al., 1995; Perrin et al., 1995; Stenzel et al., 1995). These receptors share $\sim 71 \%$ amino acid sequence similarity (Grigoriadis et al., 1996) and are distinct both in their localization in the CNS and periphery (Potter et al., 1994; Chalmers et al., 1995) and in their binding affinities for CRF and Ucn. Ucn binds with an almost 40-fold higher affinity for CRFR2 than does CRF. While CRFR1 is abundantly expressed in the cerebral cortex, cerebellum, medial septum, and anterior pituitary, CRFR2 is predominantly found in the lateral septum, ventromedial hypothalamus, and choroid plexus. In the periphery, CRFR2 is the predominant receptor and is widely distributed in the heart, skeletal muscle, vasculature, and gastrointesti-

\footnotetext{
Received Oct. 2, 2001; revised Oct. 10, 2001; accepted Oct. 16, 2001.

This work was supported in part by National Institutes of Health Grant DK-26741, by the Robert J. and Helen C. Kleberg Foundation, by the Ludwick Family Foundation, and by the Foundation for Research. T.L.B. is supported by National Research Service Award fellowship DK09841. We thank Kevin Creehan for animal assistance and Sandra Guerra for editorial assistance.

T.L.B. and R.P. contributed equally to this work.

Correspondence should be addressed to Dr. Wylie W. Vale, The Clayton Foundation for Peptide Biology, The Salk Institute, 10010 North Torrey Pines Road, La Jolla, CA 92037. E-mail: vale@salk.edu.

Copyright (C) 2001 Society for Neuroscience $\quad 0270-6474 / 01 / 220193-07 \$ 15.00 / 0$
}

nal tract (Kishimoto et al., 1995; Lovenberg et al., 1995; Perrin et al., 1995; Stenzel et al., 1995).

The CRF receptors are also distinct in the phenotypes produced by null deletion in mice. Mice deficient for CRFR1 display decreased anxiety-like behavior and have an impaired stress response (Smith et al., 1998; Timpl et al., 1998). These mice fail to display the characteristic HPA-axis response to restraint stress attributable to agenesis of the zona fasciculata region of their adrenal gland resulting from a deficiency of ACTH during development. Behaviorally, the CRFR1-mutant mice display decreased anxiety-like behavior when examined on an elevated plus maze (EPM) and in the light/dark emergence task (Smith et al., 1998). CRF levels are increased in the paraventricular nucleus (PVN) in the CRFR1-deficient mice, indicating a diminished negative feedback response attributable to decreased corticosterone levels.

In direct opposition to the CRFR1-mutant mice, CRFR2mutant mice display increased anxiety-like behavior and are hypersensitive to stress (Bale et al., 2000; Coste et al., 2000). These mice respond not only more rapidly to stress but also with greater amplitude, with mutant mouse corticosterone levels doubling control levels after 10 min of restraint (Bale et al., 2000). The CRFR2-mutant mice display increased anxiety-like behavior when examined on the elevated plus maze and the open-field test (Bale et al., 2000). CRF mRNA levels are increased in the null-mutant mice in the amygdala, a nucleus important in transduction of stress and anxiety signals (King and Meyer, 1958; Allen and Allen, 1975; Beaulieu et al., 1986; Liang et al., 1992). Ucn mRNA in the Edinger-Westphal (EW) nucleus is also increased in the CRFR2-mutant mice. The reported phenotype for 
these mice contains some discrepancies, because one group found a trend in anxiety levels in the mutant mice that did not reach significance (Coste et al., 2000), whereas another group only detected anxiety-like behavior in male but not female mutant mice (Kishimoto et al., 2000). Differences in breeding schemes and mouse strains have been proposed to explain the variation in results obtained for these mice.

To further elucidate specific roles of both CRF receptors in activation and modulation of stress and anxiety as well as maintenance of homeostasis, we have generated mice deficient in both CRFR1 and CRFR2. These mice have been analyzed in comparison with the single CRFR1- or CRFR2-mutant mice for anxietylike behaviors, stress responses, and gene expression. We have also determined mRNA expression levels for the new CRF-family ligand Ucn III (Hsu and Hsueh, 2001; Lewis et al., 2001) and vasopressin (VP) in these mice.

\section{MATERIALS AND METHODS}

Generation of CRFR1/CRFR2 double-mutant mice. To produce mice deficient for both CRF receptors, null mutant CRFR2 female mice (Bale et al., 2000) on a mixed 129:C57BL/6 background were bred to null mutant CRFR1 male mice (Smith et al., 1998) on the same mixed background, to produce offspring heterozygous for both genes. Male and female heterozygous mice were then bred to produce control, CRFR1-, CRFR2-, and double-mutant mice. All mice referred to as CRFR1- or CRFR2-mutant mice are null mutant for the specified gene and wild type for the alternate gene.

Blood collection and hormone analysis. Basal hormone samples were obtained at 08:00 A.M. For ACTH and corticosterone analyses after stress, individually housed 16 - to 20 -week-old male control and doublemutant mice were exposed to 2, 5, or $10 \mathrm{~min}$ of restraint stress in a $50 \mathrm{ml}$ conical tube (plastic tube with the bottom removed) (Bale et al., 2000). In a separate experiment, 16- to 20-week-old male control, CRFR1-, CRFR2-, and double-mutant mice were exposed to $10 \mathrm{~min}$ of restraint stress as described above to compare single receptor deficiencies with the absence of both known CRF receptors in the HPA axis stress response. Each mouse was only bled once. All samples were collected by retroorbital eye bleed from unanesthetized animals within $30 \mathrm{sec}$ of removal from the conical tube after the restraint or removal from their cage for basal samples. Plasma samples were immediately centrifuged and stored at $-80^{\circ} \mathrm{C}$ until the assay was conducted. The ACTH assay (Nichols Institute Diagnostics, San Juan Capistrano, CA) used $50 \mu \mathrm{l}$ of plasma and the corticosterone assay (ICN Biomedicals, Costa Mesa, CA) used 5 $\mu \mathrm{l}$ of plasma as measured in duplicate by radioimmunoassay kits.

Histology of adrenal and pituitary glands. Adrenal and pituitary gland tissues from 16- to 20-week-old male mice were fixed in neutral-buffered formalin (Sigma, St. Louis, MO) for $48 \mathrm{hr}$, dehydrated in $70 \%$ ethanol, and embedded in paraffin. Tissues were sectioned at $8 \mu \mathrm{m}$ thickness, deparaffinized, and stained with hematoxylin and eosin (H\&E).

Anxiety-like behavioral testing. Female and male mice were used in anxiety experiments at 16-20 weeks of age. All mice of the same sex were related within each experiment. During the week before the experiment, animals were handled on alternate days. Animals were individually housed under conditions of a regular $12 \mathrm{hr}$ light/dark cycle (lights on at 6:00 A.M., lights off at 6:00 P.M.) for $15 \mathrm{~d}$ before testing. Testing was performed as described previously (Smith et al., 1998; Bale et al., 2000). For comparisons of double-mutant mice with single-mutant mice, only CRFR1 mutants were tested. Because the anxiety testing requires either individual or group housing depending on the hypothesized outcome for anxiety levels, preliminary data indicated that the double-mutant mice phenotype was more similar to the CRFR1-mutant mice. Thus, we proceeded with individually housing the mice for these experiments. Because the CRFR2-mutant mice require group housing for anxiety testing, we did not include this group in these tests. All data sets were analyzed by ANOVA with a Newman-Keuls multiple comparison post hoc test.

$E P M$. The plus-maze apparatus was made of black Plexiglas and had two open arms $(30 \times 5 \mathrm{~cm})$ and two enclosed arms of the same size with walls $30 \mathrm{~cm}$ high. The apparatus was elevated $30 \mathrm{~cm}$ above the ground. The arms were connected by a central square $(5 \times 5 \mathrm{~cm})$ and thus the maze formed a plus sign. A $25 \mathrm{~W}$ lamp placed above the apparatus provided a 6 lux light level in the open arms. Background white noise was set at $52 \mathrm{~dB}$. All testing was conducted during the light phase of the light/dark cycle. Mice were habituated to the experimental room for $1 \mathrm{hr}$ before the behavioral testing, and the subjects were individually tested in 5 min sessions. Each mouse was placed on the center platform facing an open arm to initiate the test session. Behaviors scored were the number of open- and closed-arm entries and the time spent on the various sections of the maze. Arm entries were defined as entry of all four paws into the arm. Total-arm entries were taken as an index of locomotor activity in the plus maze. A camera mounted above the apparatus allowed the observation and scoring of the animal's behavior on a video monitor placed in an adjacent room. At the end of the test, the number of entries into and the time spent on the open arms were expressed as a percentage of the total number of arm entries and test duration, respectively.

Open-field test. The open-field apparatus consists of a white Plexiglas box $(50 \times 50 \times 22 \mathrm{~cm})$ with 16 squares $(12 \times 12 \mathrm{~cm})$ painted on the floor (12 outer and 4 inner squares). A lamp directed to the center of the field provides a 120 lux illumination on the floor. Testing was conducted during the dark phase of the light/dark cycle in a room with constant background white noise $(52 \mathrm{~dB})$. Each mouse was placed in the center of the apparatus to initiate a 10 min test session. Time (in seconds) spent in the inner squares and time (in seconds) spent grooming were quantified from a video recording.

In situ hybridization. In situ hybridization was performed on male brain tissue as described previously (Bale et al., 2000); $n=5$. Riboprobes for Ucn, CRF, and Ucn III were generated from DNA constructs made in our laboratory. The VP probe was provided by D. Richter (Institute of Cell Biology and Clinical Neurobiology, University of Hamburg, Hamburg, Germany). Slides were dipped in NTB2 liquid nuclear emulsion (Eastman Kodak, Rochester, NY) (diluted 1:1 with water), exposed for 5-10 d, photographically processed, counter-stained with hematoxylin, and coverslipped.

\section{RESULTS}

\section{HPA axis hormone analysis}

Double-mutant mice display diminished HPA responses to stress. To examine the response of the HPA axis to stress, male doublemutant and control mice were exposed to a restraint stress of varying lengths of time. Plasma concentrations of ACTH and corticosterone were measured in samples collected after each of the 2, 5, or $10 \mathrm{~min}$ restraint periods. ACTH and corticosterone levels in control mice were significantly more elevated after all time points of the restraint stress than the hormone levels of the double-mutant mice (Fig. $1 A, B$ ). To compare the HPA response to stress of the double-mutant mice with the CRFR1 or CRFR2 single-mutant mice, males were exposed to $10 \mathrm{~min}$ of restraint stress. Plasma ACTH and corticosterone levels for double-mutant mice were significantly lower than those obtained for CRFR1 single-mutant mice (Fig. 1C,D). As predicted, both CRFR1- and double-mutant hormone levels were substantially lower than control or CRFR2-mutant mouse levels. Basal morning ACTH and corticosterone levels were also measured. No differences were found in ACTH levels between control, CRFR1-, CRFR2-, and double-mutant mice (Fig. 1E). Corticosterone levels were significantly lower in CRFR1- and double-mutant mice compared with control and CRFR2-mutant levels (Fig. $1 F$ ). Double-mutant corticosterone levels were significantly lower than CRFR1-mutant levels [Fig. 1, $a$ was significantly different from $b$ and $c(p<0.01)$ and $b$ was significantly different from $c(p<0.05)]$.

\section{Histology of adrenal and pituitary glands}

To determine the effect of a deficiency for both CRFR1 and CRFR2 on pituitary and adrenal gland development, tissues from adult male double-mutant and control mice were sectioned and stained with hematoxylin and eosin. A pronounced atrophy of the adrenal gland from the double-mutant mouse was detected resulting from hypoplasia of the zona fasciculata region of the 
A

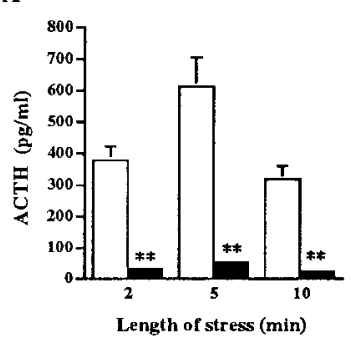

C
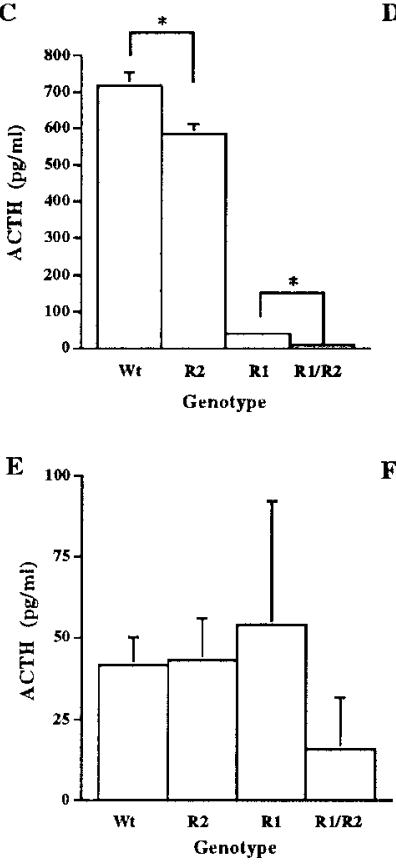

B

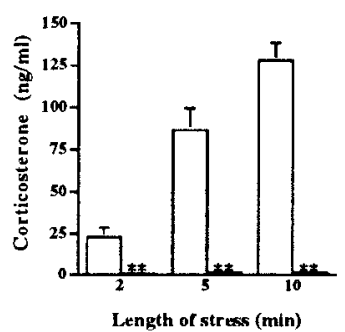

D

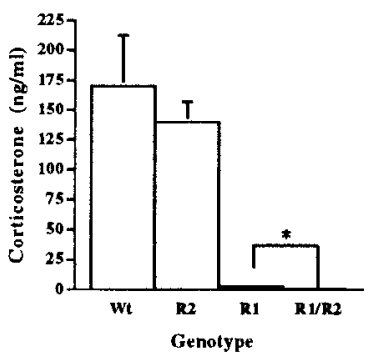

$\mathbf{F}$

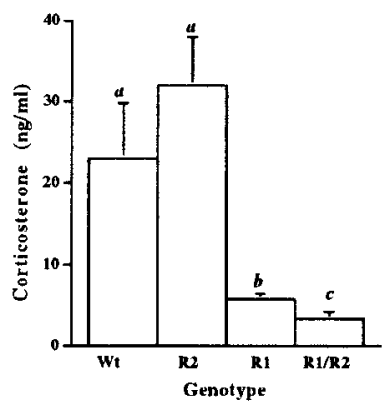

Figure 1. Impairment of the HPA axis response to stress in doublemutant animals. Time course of restraint stress effects on ACTH $(A)$ and corticosterone $(B)$ plasma levels at 9:00 A.M. ( $n=8$ for wild-type mice, white bars; $n=7$ for double-mutant mice, black bars; mean \pm SEM). **Significantly different from wild-type controls at the same time point; $p<0.001$ by ANOVA, Scheffe's post hoc test. Comparison of ACTH $(C)$ and corticosterone $(D)$ plasma levels in control, CRFR1-, CRFR2-, and CRFR1/2-mutant mice after 10 min of restraint stress $(n=4$; mean \pm SEM; ${ }^{*} p<0.05$ by ANOVA, Fisher's post hoc test). Basal ACTH $(E)$ and corticosterone $(F)$ plasma levels (taken by retro-orbital eyebleed at 08:00 A.M.) for wild-type, CRFR1-, CRFR2-, and CRFR1/2-mutant male mice. No statistical differences were found between groups for ACTH levels. For corticosterone, $a$ was significantly different from $b$ and $c(p<0.01)$ and $b$ was significantly different from $c(p<0.05$ by ANOVA, Scheffe's post hoc test) ( $n=4$ for wild-type and CRFR2 mice; $n=3$ for CRFR 1 and CRFR1/2 mice; mean \pm SEM).

adrenal cortex. The reduced size of the adrenal gland as well as agenesis of the cortex was similar to that seen in the CRFR1mutant mouse (Fig. 2). Histology of the pituitary gland revealed no gross anatomical abnormalities (data not shown).

\section{EPM}

Results from the anxiety tests revealed a sexual dichotomy in anxiety-like behaviors in these mice. Female double-mutant mice spent more time on the open arms of the plus-maze apparatus and entered these open arms more frequently than did wild-type mice; these female mice were similar to the CRFR1-mutant mice (Fig. 3A). A significant effect was found for both percentage of entries into the open arms $\left(F_{(2,52)}=3.183 ; p<0.05\right)$ and percentage of time spent in open arms $\left(F_{(2,55)}=4.53 ; p<0.05\right)$.
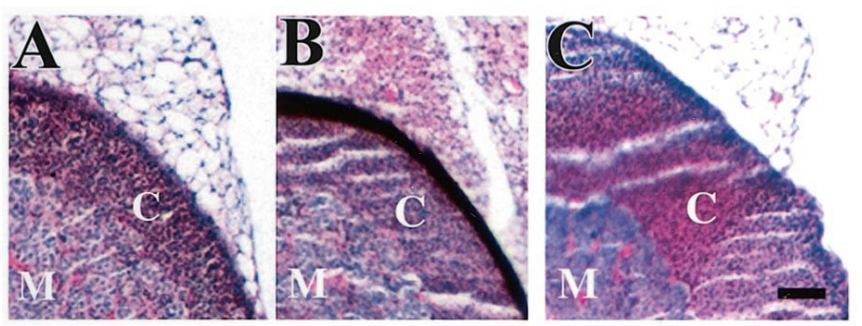

Figure 2. Double-mutant adrenal glands have atrophied cortex, similar to CRFR1 adrenal glands. H\&E staining of the adrenal gland from double-mutant $(A)$, CRFR1-mutant $(B)$, and wild-type $(C)$ mice is shown. Note that there is no difference in adrenal gland cortex size between the CRFR1-mutant mice and the double-mutant mice. $C$, Cortex; $M$, medulla. $n=3$. Scale bar, $50 \mu \mathrm{m}$.

Overall activity as measured by total arm entries was not different between wild-type $(17.75 \pm 1.29)$, CRFR1-mutant $(16.75 \pm 3.12)$, or double-mutant $(15.91 \pm 0.90)$ female mice $\left(F_{(2,58)}=0.74 ; p=\right.$ $0.48)$. There were no significant differences between male genotypes in the EPM for percentage of entries into the open arms $\left(F_{(2,25)}=1.17 ; p=0.33\right)$ or percentage of time spent in open arms $\left(F_{(2,26)}=0.95 ; p=0.40\right)$ (Fig. $\left.3 B\right)$. Overall activity as measured by total arm entries was not different between wild-type (17.00 \pm 1.41), CRFR1-mutant $(15.38 \pm 2.67)$, or double-mutant (14.36 \pm $2.15)$ male mice $\left(F_{(2,26)}=0.46 ; p=0.64\right)$. In analyses between male and female mice, a significant difference was found between double-mutant males and females for percentage of entries into the open arms of the EPM $\left(t_{(35)}=2.137 ; p<0.05\right)$. No differences were detected between male and female control mice $\left(t_{(37)}=\right.$ $0.68 ; p=0.50)$ or between male and female CRFR1-mutant mice $\left(t_{(10)}=0.02 ; p=0.98\right)$ for percentage of entries into the open arms of the EPM.

\section{Open-field test}

Several parameters from the results of the open-field test confirm the observations made in the EPM. As an indication of lower anxiety-like behavior, female CRFR1- and double-mutant mice produced fewer fecal boli during the experiment than controls $\left(F_{(2,42)}=8.41 ; p=0.0008\right)$. Time spent in the center of the open-field apparatus was not different between groups $\left(F_{(2,42)}=\right.$ 2.14; $p=0.12$ ). As with the EPM, the male double-mutant mice showed no significant difference in time spent in the center of the open field compared with control and CRFR1-mutant male mice $\left(F_{(2,25)}=1.88 ; p=0.17\right)$. However, in another parameter of anxiety measurement, male double-mutant mice had more bouts of grooming than either control or CRFR1-mutant male mice $\left(F_{(2,24)}=5.49 ; p=0.01\right)$. Comparisons between females and males for time spent in the center of the open field found a significant difference between male and female double-mutant mice $\left(t_{(24)}=2.25 ; p<0.05\right)$ but not for control mice $\left(t_{(32)}=0.49\right.$; $p=0.63)$ or CRFR1 mice $\left(t_{(11)}=2.14 ; p=0.06\right)$ (Fig. $3 C$ ). Comparisons of male and female mice also revealed that male double-mutant mice produced significantly more fecal boli during the experiment than female double-mutant mice $\left(t_{(25)}=2.82 ; p<\right.$ $0.01)$. No differences were found between males and females for control mice $\left(t_{(31)}=0.75 ; p=0.46\right)$ or CRFR1-mutant mice $\left(t_{(11)}\right.$ $=0.99 ; p=0.34)$.

\section{Effect of dam's genotype on anxiety-like behavior}

A significant correlation was found between the dam's CRFR2 genotype and the male pup's anxiety-like behavior as detected in our experiments. If the mother was heterozygous or homozygous 


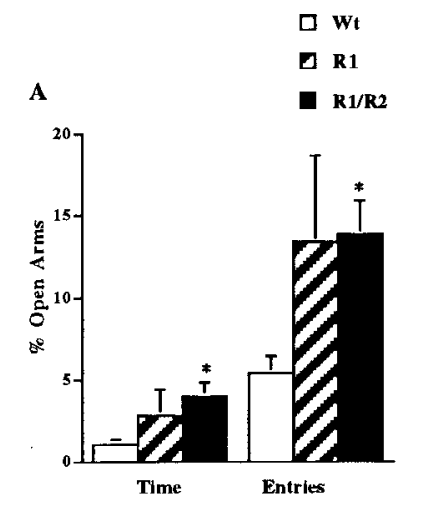

$\mathbf{B}$
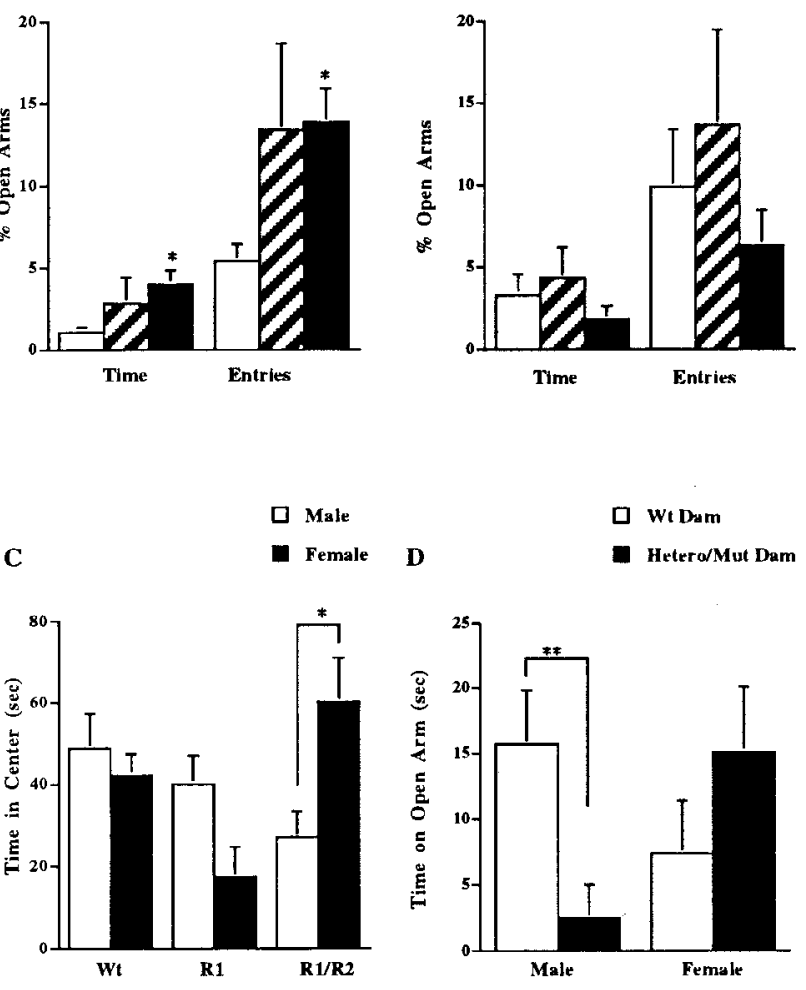

Figure 3. Sexual dichotomy in anxiety-like behaviors of double-mutant mice. Decreased anxiety-like behavior of double-mutant animals as measured in the elevated plus maze $(A, B)$ test of anxiety is shown. All tests were conducted on individually housed 16 - to 20 -week-old female and male mice. All results are reported as mean \pm SEM. $A$, Percentage of time spent in the open arms and number of entries into the open arms were significantly more for the female double-mutant mice $(n=27)$ than for the wild-type controls $(n=27)\left({ }^{*} p<0.05\right)$. Female CRFR1-mutant mice were not significantly different from controls $(n=4)$. $B$, Percentage of time spent in the open arms and number of entries into the open arms were not significantly different between male double-mutant mice $(n=$ 11), CRFR1-mutant mice $(n=8)$, and wild-type mice $(n=10)$. $C$, Comparison of males and females on the open-field test. Male doublemutant mice spend significantly less time in the center of the open field than double-mutant females $\left(n=10\right.$ males; $n=16$ females; $\left.{ }^{*} p<0.05\right)$. No significant differences were found between male and female wild-type mice ( $n=10$ males; $n=24$ females; $p=0.63$ ) or CRFR1-mutant mice $(n=8$ males; $n=5$ for females; $p=0.06)$. $D$, A significant correlation was found between the dam's CRFR2 genotype and the male pup's anxietylike behavior. If the mother was heterozygous or homozygous for CRFR2 mutation, the pup, regardless of its genotype, showed significantly more anxiety-like behavior (as measured by time spent on the open arm of the elevated plus maze). **Significantly different $(p<0.05)$. For male pups born to wild-type dams, $n=4$ CRFR1-mutant mice and $n=6$ wild-type mice. For male pups born to either heterozygous or mutant dams, $n=4$ CRFR1-mutant mice, $n=11$ double-mutant mice, and $n=4$ wild-type mice. For female pups born to wild-type dams, $n=3$ CRFR1-mutant mice and $n=18$ wild-type mice. For female pups born to either heterozygous or mutant dams, $n=2$ CRFR1-mutant mice, $n=27$ double-mutant mice, and $n=9$ wild-type mice.

for CRFR2 mutation, the pup, regardless of its genotype, showed significantly more anxiety-like behavior (as measured by time spent on the open arm of the elevated plus maze) (Fig. 3D). This genotype affected male pups but did not have a significant effect on females. Although the anxiety-like behavioral response is sexually dimorphic in the double-mutant mice, the female mice tested for anxiety-like behaviors were not estrous cycled. Because activity can change over the estrous cycle, we cannot rule out a possible behavioral effect on the female mice. The CRFR1 genotype of the dam had no effect on anxiety-like behavior for females or males, nor did the genotype of the sire (data not shown). Females are always removed from the male's cage before giving birth; thus the pups have no interaction with the behavior of the sire.

\section{CRF, Ucn III, and VP mRNA levels are increased in the absence of both receptors}

To determine the alteration in gene expression for CRF family ligands found in the hypothalamus as well as ligands associated with increased HPA activity, in situ hybridization was performed. CRF mRNA levels were increased in the PVN in the absence of both CRFR1 and CRFR2. Whereas control and CRFR2-mutant mice display relatively low levels of CRF, the double-mutant and CRFR1-mutant mice show significantly elevated levels of expression (Fig. 4A-D). Similar to CRFR1-mutant mice, corticosterone replacement decreased CRF levels in the double-mutant PVN, but these levels still remained elevated compared with control mice (Fig. 4E,F). CRF mRNA levels are not increased in the central nucleus of the amygdala (cAmyg) and Ucn mRNA levels are not increased in the EW nucleus of double-mutant mice compared with control-mouse levels (data not shown). These results for the double-mutant mice are similar to those reported previously for CRFR1-mutant mice (Smith et al., 1998; Timpl et al., 1998). Ucn III mRNA is dramatically increased in the perifornical region lateral to the PVN (possibly a portion of the magnocellular region of the lateral PVN) in the CRFR2- and double-mutant mice (Fig. 4G-J). Lower levels of expression were detected in the wild-type and CRFR1-mutant mice. PVN VP mRNA levels are also increased in both CRFR2- and doublemutant mice compared with CRFR1-mutant and control mice (Fig. $4 K-N)$.

\section{DISCUSSION}

Mice deficient for both known CRF receptors, CRFR1 and CRFR2, were generated and analyzed for hormonal and behavioral responses to stress. In the absence of either known receptor, double-mutant mice display a very small HPA axis response to a restraint stress. ACTH and corticosterone levels after restraint stress were significantly lower in the double-mutant mice than in CRFR1-mutant mice, suggesting a possible role of CRFR2 in mediation of HPA-axis sensitivity. Mice deficient in CRFR2 are hypersensitive to stress, displaying a rapid HPA-axis response (Bale et al., 2000), whereas CRFR1-mutant mice have an impaired stress response attributable to the absence of CRFR1 in the anterior pituitary corticotropes. Although CRFR1 is abundantly expressed in the anterior pituitary, CRFR2 is not, suggesting a new involvement of CRFR2 in HPA axis activation that may occur upstream of corticotropic cell stimulation, possibly in CRF cell bodies within the hypothalamus. Basal levels of ACTH did not differ between groups, whereas corticosterone levels varied greatly. We detected significantly lower levels of corticosterone in the double-mutant mice than in the CRFR1-mutant mice. Because both groups' adrenal glands were similar in appearance, these results also support a novel role of CRFR2 in regulation of the HPA axis. Decreased levels of ACTH during development likely account for agenesis of the adrenal cortex in the doublemutant mice, as was seen in the previously reported CRFR1mutant mice (Smith et al., 1998). These data indicate that both 

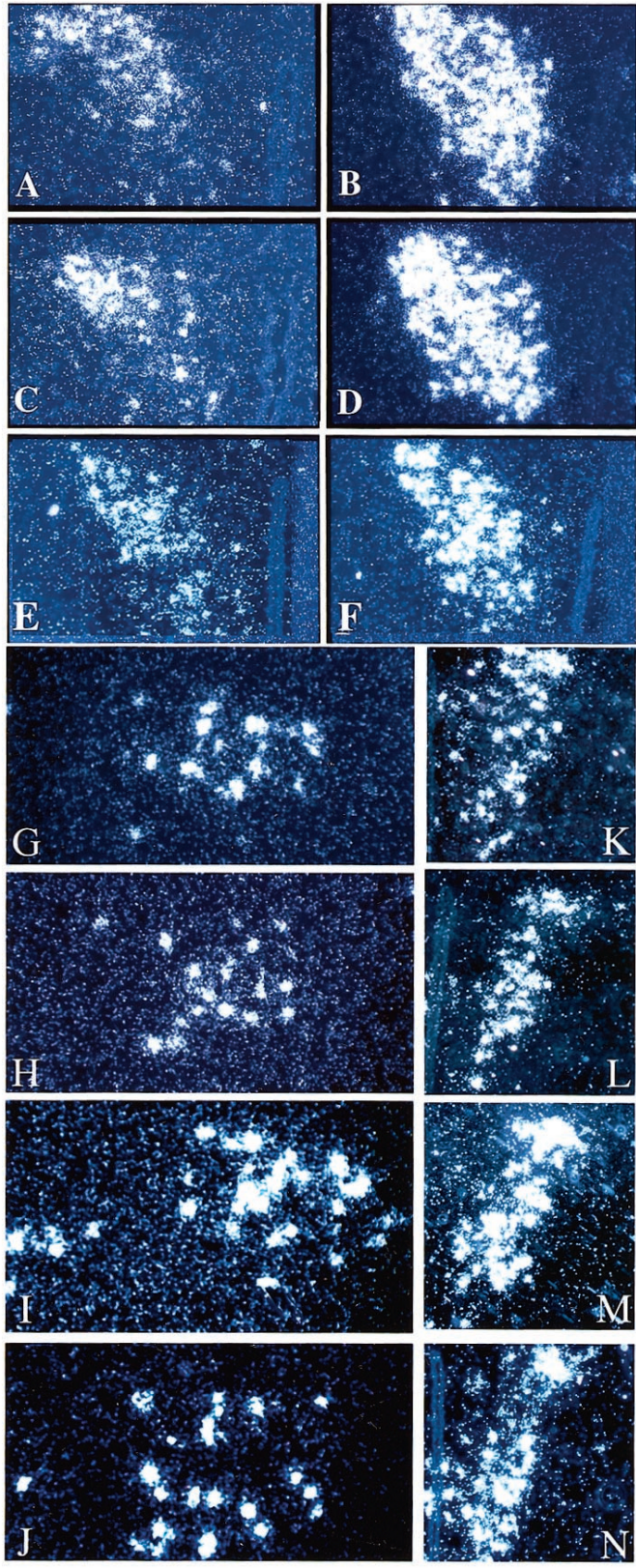

Figure 4. CRF, Ucn III, and VP mRNA levels are increased in the absence of both receptors Silver grains by in situ hybridization for CRF mRNA in the PVN $(A-F)$, Ucn III mRNA in the lateral perifornical region $(G-J)$, and VP in the PVN $(K-N)$ comparing wild-type mice $(A$, $E, G, K)$, CRFR1-mutant mice $(B, H, L)$, CRFR2-mutant mice $(C, I, M)$, and double-mutant mice $(D, F, J, N)$ are shown. Double-mutant mice were also treated with corticosterone $(F)$ and compared with wild-type mouse CRF mRNA levels $(E)$. Corticosterone-treated mice were given 25 $\mu \mathrm{g} / \mathrm{ml}$ corticosterone in their drinking water for $14 \mathrm{~d}$ before they were killed.

CRF receptors, CRFR1 and CRFR2, are important for maintenance and regulation of homeostasis in response to stress (Weninger et al., 1999).

Results from testing for anxiety-like behaviors showed that the double-mutant mice are sexually dichotomous. Female doublemutant mice display decreased levels of anxiety-like behaviors compared with wild-type mice. Anxiolytic-like profiles were obtained in the behavioral parameters derived from the two differ- ent anxiety models tested. Double-mutant female mice entered the open arms of the EPM more frequently and spent more time in the open arms than control mice. No significant differences between groups were found in center visits in the open-field test, but female double-mutant mice produced significantly fewer fecal boli during the experiment, which is an indicator of decreased anxiety. These results suggest an anxiolytic-like phenotype for the female double-mutant mice. However, male double-mutant mice did not display the anxiolytic-like behavior detected in the females. In addition, in the open-field test, male double-mutant mice spent significantly more time grooming than either controls or CRFR1-mutant mice, indicative of anxiogenic-like behavior. In comparisons done between male and female mice in each of the anxiety tasks, the double-mutant female mice were significantly more anxiolytic than the males. Females spent significantly more time on the open arms of the EPM and in the center of the open field and produced significantly fewer fecal boli during testing than the males. However, no differences were detected between males and females of either control or CRFR1-mutant mice.

Surprisingly, during behavioral testing we found that the male CRFR1-mutant mice did not display the characteristic robust anxiolytic-like behavior reported for these mice (Smith et al., 1998; Timpl et al., 1998; Contarino et al., 1999). By examining differences in breeding schemes, we have found a significant correlation between the genotype of the dam and the anxiety-like behavior detected in the male mice. If the dam is heterozygous or homozygous for the CRFR2 mutation, the pup, regardless of its genotype, is significantly more likely to show anxiogenic-like behavior. This correlation was only significant for male pups, not for female pups. These results suggest then that the reason CRFR1-mutant male mice previously reported to display dramatic anxiolytic-like behaviors are now not statistically different from controls is attributable to an effect of their mother's genotype. Previous studies have well defined the nurturing roll of the dam and how this behavior may affect the adult anxiety of the pup, suggesting that a low-nurturing mother leads to a highanxiety pup (Zaharia et al., 1996; Caldji et al., 1998). In addition, studies have also shown that the stress hormone levels of the dam during pregnancy affect the anxiety levels of the pups (Takahashi et al., 1988, 1990, 1992; Takahashi and Kalin, 1991; Cratty et al., 1995; Vallee et al., 1997). Therefore, either the behavioral or endocrine state of the dam may be affecting the anxiety status of the mice. Our laboratory is currently examining both of these hypotheses. Because we have reported previously that the CRFR2-mutant mice display increased anxiety-like behavior and a hypersensitivity to stress, it is likely that this phenotype is affecting the behavior of pups reared by "anxious" and "stressed" mothers.

Previous reports using alternate techniques have also demonstrated independent roles for CRF receptors in anxiety and stress responses. Treatment with CRFR1-selective antagonists results in decreased anxiety-like effects in rodents (Lundkvist et al., 1996; Griebel et al., 1998; Radulovic et al., 1999) and monkeys (Habib et al., 2000). In direct contrast, increased levels of anxiety-like behavior were detected in mice deficient for CRFR2 (Bale et al., 2000; Kishimoto et al., 2000). Thus, evidence exists in favor of opposite functional roles for the two known CRF receptors: activation of CRFR1 may be responsible for increased anxietylike responses, and stimulation of CRFR2 may produce anxiolytic-like effects. Regulation of the relative contribution of 
the two CRF receptor subtypes to brain CRF pathways may be essential in coordinating physiological responses to stressors.

CRF, Ucn, Ucn III, and VP mRNA levels were examined by in situ hybridization in the CNS of control, CRFR1-, CRFR2-, and double-mutant mice. CRF was dramatically increased in the PVN of double-mutant mice, but no difference was detected in the cAmyg. Interestingly, these results are similar to those reported for the CRFR1-mutant mice (Smith et al., 1998). After corticosterone replacement, although decreasing in expression, CRF mRNA levels remained elevated in the PVN of double-mutant mice compared with control levels. This suggests that the increased CRF mRNA is not entirely attributable to diminished negative feedback and may indicate another regulatory mechanism for CRF expression that may involve CRFR2. Unlike the CRFR2-mutant mice, the double-mutant mice show no increases in mRNA for CRF in the cAmyg (Bale et al., 2000). These results suggest that the increased CRF mRNA in the cAmyg and accordingly the anxiety-like behavior detected in the CRFR2-mutant mice may be attributable to unimpeded CRFR1 activity. This increase in anxiety-like behavior was also reported in CRF binding-protein-deficient mice, which show increased CRF levels in the brain (Karolyi et al., 1999). The increased level of Ucn mRNA in the EW nucleus found in the CRFR2-mutant mice was not observed in the double-mutant mice, suggesting again that CRFR1 activity is responsible for the increased ligand levels in the absence of CRFR2 (Weninger et al., 2000). Because VP also increases ACTH release from anterior pituitary corticotropes (Vale and River, 1977; Liu et al., 1983; DeBold et al., 1984; Rivier et al., 1984; Bilezikjian and Vale, 1987), we examined VP mRNA levels in the PVN of these mice. VP expression was increased in both the CRFR2- and double-mutant mice compared with control and CRFR1-mutant levels. Increased VP in the CRFR2-mutant mice may explain the hypersensitivity of the HPA axis in response to stress, suggesting that increased VP is augmenting the CRF response. The new CRFR2-specific ligand Ucn III was also examined in the hypothalamus in these mice. We found that Ucn III mRNA levels were increased in the perifornical region lateral to the PVN in CRFR2- and double-mutant mice (Lewis et al., 2001). These results support a specific interaction between CRFR2 and Ucn III and may be indicative of a negative feedback regulation for Ucn III. Afferent projections from the lateral perifornical region innervate the PVN and therefore may suggest an involvement of Ucn III and CRFR2 in HPA axis regulation. Because only male mice were examined for gene expression, sexually dimorphic patterns of gene expression have not yet been studied.

In summary, mice deficient for both known CRF receptors display altered anxiety-like behavior and an impaired HPA response to stress. These results confirm a dominant role for CRFR1 in activation of the HPA axis during stress and also bring to light the role of CRFR2 in modulation of the action of CRFR1 as well as its independent actions in HPA axis activity. Anxietylike behaviors measured in these mice indicate a sexual dichotomy in levels of anxiety in the absence of both known CRF receptors. In addition, these mice provide support for the importance of maternal behavior on the development of pup responses and coping abilities.

\section{REFERENCES}

Allen JP, Allen CF (1975) Amygdalar participation in tonic ACTH secretion in the rat. Neuroendocrinology 19:115-125.

Bale TL, Contarino A, Smith GW, Chan R, Gold LH, Sawchenko PE, Koob GF, Vale WW, Lee KF (2000) Mice deficient for corticotropin- releasing hormone receptor-2 display anxiety-like behaviour and are hypersensitive to stress. Nat Genet 24:410-414.

Beaulieu S, Di Paolo T, Barden N (1986) Control of ACTH secretion by the central nucleus of the amygdala: implication of the serotoninergic system and its relevance to the glucocorticoid delayed negative feedback mechanism. Neuroendocrinology 44:247-254.

Bilezikjian LM, Vale WW (1987) Regulation of ACTH secretion from corticotrophs: the interaction of vasopressin and CRF. Ann NY Acad Sci 512:85-96.

Caldji C, Tannenbaum B, Sharma S, Francis D, Plotsky PM, Meaney MJ (1998) Maternal care during infancy regulates the development of neural systems mediating the expression of fearfulness in the rat. Proc Natl Acad Sci USA 95:5335-5340.

Chalmers DT, Lovenberg TW, De Souza EB (1995) Localization of novel corticotropin-releasing factor receptor (CRF2) mRNA expression to specific subcortical nuclei in rat brain: comparison with CRF1 receptor mRNA expression. J Neurosci 15:6340-6350.

Chen R, Lewis KA, Perrin MH, Vale WW (1993) Expression cloning of a human corticotropin-releasing-factor receptor. Proc Natl Acad Sci USA 90:8967-8971.

Contarino A, Dellu F, Koob GF, Smith GW, Lee KF, Vale W, Gold LH (1999) Reduced anxiety-like and cognitive performance in mice lacking the corticotropin-releasing factor receptor 1. Brain Res 835:1-9.

Coste SC, Kesterson RA, Heldwein KA, Stevens SL, Heard AD, Hollis JH, Murray SE, Hill JK, Pantely GA, Hohimer AR, Hatton DC, Phillips TJ, Finn DA, Low MJ, Rittenberg MB, Stenzel P, StenzelPoore MP (2000) Abnormal adaptations to stress and impaired cardiovascular function in mice lacking corticotropin-releasing hormone receptor-2. Nat Genet 24:403-409.

Cratty MS, Ward HE, Johnson EA, Azzaro AJ, Birkle DL (1995) Prenatal stress increases corticotropin-releasing factor (CRF) content and release in rat amygdala minces. Brain Res 675:297-302.

DeBold CR, Sheldon WR, DeCherney GS, Jackson RV, Alexander AN, Vale W, Rivier J, Orth DN (1984) Arginine vasopressin potentiates adrenocorticotropin release induced by ovine corticotropin-releasing factor. J Clin Invest 73:533-538.

Griebel G, Perrault G, Sanger DJ (1998) Characterization of the behavioral profile of the non-peptide CRF receptor antagonist CP-154,526 in anxiety models in rodents. Comparison with diazepam and buspirone. Psychopharmacology (Berl) 138:55-66.

Grigoriadis DE, Liu XJ, Vaughn J, Palmer SF, True CD, Vale WW, Ling N, De Souza EB (1996) ${ }^{125}$ I-Tyro-sauvagine: a novel high affinity radioligand for the pharmacological and biochemical study of human corticotropin-releasing factor $2 \alpha$ receptors. Mol Pharmacol 50:679-686.

Habib KE, Weld KP, Rice KC, Pushkas J, Champoux M, Listwak S, Webster EL, Atkinson AJ, Schulkin J, Contoreggi C, Chrousos GP, McCann SM, Suomi SJ, Higley JD, Gold PW (2000) Oral administration of a corticotropin-releasing hormone receptor antagonist significantly attenuates behavioral, neuroendocrine, and autonomic responses to stress in primates. Proc Natl Acad Sci USA 97:6079-6084.

Hsu SY, Hsueh AJ (2001) Human stresscopin and stresscopin-related peptide are selective ligands for the type 2 corticotropin-releasing hormone receptor. Nat Med 7:605-611.

Karolyi IJ, Burrows HL, Ramesh TM, Nakajima M, Lesh JS, Seong E, Camper SA, Seasholtz AF (1999) Altered anxiety and weight gain in corticotropin-releasing hormone-binding protein-deficient mice. Proc Natl Acad Sci USA 96:11595-11600.

King FA, Meyer PM (1958) Effects of amygdaloid lesions upon septal hyperemotionality in the rat. Science 128:655-656.

Kishimoto T, Pearse II RV, Lin CR, Rosenfeld MG (1995) A sauvagine/ corticotropin-releasing factor receptor expressed in heart and skeletal muscle. Proc Natl Acad Sci USA 92:1108-1112.

Kishimoto T, Radulovic J, Radulovic M, Lin CR, Schrick C, Hooshmand F, Hermanson O, Rosenfeld MG, Spiess J (2000) Deletion of crhr2 reveals an anxiolytic role for corticotropin-releasing hormone receptor-2. Nat Genet 24:415-419.

Lewis K, Li C, Perrin MH, Blount A, Kunitake K, Donaldson C, Vaughan J, Reyes TM, Gulyas J, Fischer W, Bilezikjian L, Rivier J, Sawchenko PE, Vale WW (2001) Identification of urocortin III, an additional member of the corticotropin-releasing factor (CRF) family with high affinity for the CRF2 receptor. Proc Natl Acad Sci USA 98:7570-7575.

Liang KC, Melia KR, Campeau S, Falls WA, Miserendino MJ, Davis M (1992) Lesions of the central nucleus of the amygdala, but not the paraventricular nucleus of the hypothalamus, block the excitatory effects of corticotropin-releasing factor on the acoustic startle reflex J Neurosci 12:2313-2320.

Liu JH, Muse K, Contreras P, Gibbs D, Vale W, Rivier J, Yen SS (1983) Augmentation of ACTH-releasing activity of synthetic corticotropin releasing factor (CRF) by vasopressin in women. J Clin Endocrinol Metab 57:1087-1089.

Lovenberg TW, Liaw CW, Grigoriadis DE, Clevenger W, Chalmers DT, De Souza EB, Oltersdorf T (1995) Cloning and characterization of a 
functionally distinct corticotropin-releasing factor receptor subtype from rat brain. Proc Natl Acad Sci USA 92:836-840.

Lundkvist J, Chai Z, Teheranian R, Hasanvan H, Bartfai T, Jenck F, Widmer U, Moreau JL (1996) A nonpeptidic corticotropin releasing factor receptor antagonist attenuates fever and exhibits anxiolytic-like activity. Eur J Pharmacol 309:195-200.

Perrin M, Donaldson C, Chen R, Blount A, Berggren T, Bilezikjian L, Sawchenko P, Vale W (1995) Identification of a second corticotropinreleasing factor receptor gene and characterization of a cDNA expressed in heart. Proc Natl Acad Sci USA 92:2969-2973.

Potter E, Sutton S, Donaldson C, Chen R, Perrin M, Lewis K, Sawchenko PE, Vale W (1994) Distribution of corticotropin-releasing factor receptor mRNA expression in the rat brain and pituitary. Proc Natl Acad Sci USA 91:8777-8781.

Radulovic J, Ruhmann A, Liepold T, Spiess J (1999) Modulation of learning and anxiety by corticotropin-releasing factor (CRF) and stress: differential roles of CRF receptors 1 and 2. J Neurosci 19:5016-5025.

Rivier C, Rivier J, Mormede P, Vale W (1984) Studies of the nature of the interaction between vasopressin and corticotropin-releasing factor on adrenocorticotropin release in the rat. Endocrinology 115:882-886.

Smith GW, Aubry JM, Dellu F, Contarino A, Bilezikjian LM, Gold LH, Chen R, Marchuk Y, Hauser C, Bentley CA, Sawchenko PE, Koob GF, Vale W, Lee KF (1998) Corticotropin releasing factor receptor 1-deficient mice display decreased anxiety, impaired stress response, and aberrant neuroendocrine development. Neuron 20:1093-1102.

Stenzel P, Kesterson R, Yeung W, Cone RD, Rittenberg MB, StenzelPoore MP (1995) Identification of a novel murine receptor for corticotropin-releasing hormone expressed in the heart. Mol Endocrinol 9:637-645.

Takahashi LK, Kalin NH (1991) Early developmental and temporal characteristics of stress-induced secretion of pituitary-adrenal hormones in prenatally stressed rat pups. Brain Res 558:75-78.

Takahashi LK, Kalin NH, Barksdale CM, Vanden Burgt JA, Brownfield MS (1988) Stressor controllability during pregnancy influences pituitary-adrenal hormone concentrations and analgesic responsiveness in offspring. Physiol Behav 42:323-329.
Takahashi LK, Baker EW, Kalin NH (1990) Ontogeny of behavioral and hormonal responses to stress in prenatally stressed male rat pups. Physiol Behav 47:357-364.

Takahashi LK, Haglin C, Kalin NH (1992) Prenatal stress potentiates stress-induced behavior and reduces the propensity to play in juvenile rats. Physiol Behav 51:319-323.

Timpl P, Spanagel R, Sillaber I, Kresse A, Reul JM, Stalla GK, Blanquet V, Steckler T, Holsboer F, Wurst W (1998) Impaired stress response and reduced anxiety in mice lacking a functional corticotropinreleasing hormone receptor. Nat Genet 19:162-166.

Vale W, River C (1977) Substances modulating the secretion of ACTH by cultured anterior pituitary cells. Fed Proc 36:2094-2099.

Vale W, Spiess J, Rivier C, Rivier J (1981) Characterization of a 41residue ovine hypothalamic peptide that stimulates secretion of corticotropin and $\beta$-endorphin. Science 213:1394-1397.

Vallee M, Mayo W, Dellu F, Le Moal M, Simon H, Maccari S (1997) Prenatal stress induces high anxiety and postnatal handling induces low anxiety in adult offspring: correlation with stress-induced corticosterone secretion. J Neurosci 17:2626-2636.

Vaughan J, Donaldson C, Bittencourt J, Perrin MH, Lewis K, Sutton S, Chan R, Turnbull AV, Lovejoy D, Rivier C, et al (1995) Urocortin, a mammalian neuropeptide related to fish urotensin I and to corticotropin-releasing factor. Nature 378:287-292.

Weninger SC, Dunn AJ, Muglia LJ, Dikkes P, Miczek KA, Swiergiel AH, Berridge CW, Majzoub JA (1999) Stress-induced behaviors require the corticotropin-releasing hormone $(\mathrm{CRH})$ receptor, but not $\mathrm{CRH}$. Proc Natl Acad Sci USA 96:8283-8288.

Weninger SC, Peters LL, Majzoub JA (2000) Urocortin expression in the Edinger-Westphal nucleus is up-regulated by stress and corticotropinreleasing hormone deficiency. Endocrinology 141:256-263.

Zaharia MD, Kulczycki J, Shanks N, Meaney MJ, Anisman H (1996) The effects of early postnatal stimulation on Morris water-maze acquisition in adult mice: genetic and maternal factors. Psychopharmacology (Berl) 128:227-239. 